Topik: Demokrasi Indonesia dan Citanegara Integralistik, Arifin, SS. Tambunan

\title{
Demokrasi Indonesia dan Citanegara Integralistik
}

\section{Sebuah tanggapan terhadap tulisan Kotan Y. Stefanus}

\section{Arifin S.S. Tambunan}

The life of a state is a continuos process of intgration, There must be a dynamic stugle to make an integrated state happen. This article tehoritically illustrates the idea of Soepomo concerning the Integralistic State and criticizes some approaches opposing to it. Different from other writings, this article combines legal ang political approaches.

\section{Pendahuluan}

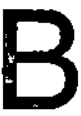

anyak orang tidak menyadari bahwa UUD 1945 adalah unik. Tidak ada UUD negara lain yang menyerupainya, baik mengenai sejarahnya maupun mengenai sistematika dan isinya. Konsep UUD 1945 dibahas dan dirumuskan oleh BPUPKI yang dibentuk Jepang sewaktu penjajahan Jepang. Tetapi peresmian UUD 1945 terjadi sewaktu Indonesia sudah merdeka dan setelah dibahas ulang oleh PPKI bentukan bangsa Indonesia sendiri.'

Perumus utama UUD 1945 Prof. Mr. dr. R. Supomo telah mendapat banyak kritik khususnya mengenai cita negara Integralistik yang dikemukakanya di BPUPKI. Kritik yang paling tajam dilontarkàn. oleh Marsilam Simanjuntak ${ }^{2}$ dan Daniel Dhakidae $^{3}$ Kritik Marsillam telah mendapat tanggapan dari Abdul Hamid SA4 ${ }^{4}$, Azharis, A. Rachman Zainuddin ${ }^{6}$, Suryo Pugiarto ${ }^{7}$ dan Soehardjo Sastrosoehardjo ${ }^{8}$.'Kemudian Dardji Darmodiharjo ${ }^{9}$ memberikan ulasan mengenai negara Integralistik. Dengan tulisan Kotan Y Stefanus dalam Jurnal in ${ }^{10}$

'. A.S.S. Tambunan, Dualisme Naskah UUD 1945, Jakarta, Pustaka Sinar Harapan, 1993.
2.Marsilam Simanjuntak, Pandangan Negara Integralistik, Jakarta, Pustaka Utama Grafiti, 1994.

3. Daniel Dhakidae, Ironi Akademik Pandangan Negara Integralistik, Kompas, Senen, 22 Agustus 1994.

4. Abdul Hamid SA, Peranan Keputusan Presiden $\mathrm{Rl}$ dalam Penyelenggaraan. Pemerintahan Negara, Suatu Studi Analisis mengenai Keputusan Presiden yang berfungsi pengaturan [disertasi], Jakarta, Fakultas Pasca Sarjana UI, 1990, hal.71-75.

5. Azahry, Negara Hukum Indonesia, Analisis Yuridis normatif tentang unsur-unsumya [disertasi], Jakarta, UI-Press, 1995, hal.77.

6. A. Razhman Zainuddin, "Moralitas dalam Pandangan Hegef", Kompas, sabtu, 1 September 1994.

7. Suryo Pugiarto, "Memahamitentang Negara Integralistik", Suara Pembaharuan, senin, 5 September, 1994.

${ }^{8}$. Soehardjo Sastrosoehardjo,"Negara Integralistik Masihkah diragukan?" Suara Merdeka, Senin, 12 September 1994.

9. Dardjo Darmodihardjo, "Citanegara Integralistik Indonesia dalam UUD 1945", Era Hukum, Jurnal IImiah Hukum, No $33 / \mathrm{Th}$ I/ Januari 1995, hal. 1-11.

10 .Kotan Y. Stefanus, "Demokrasi Indonesia dalam Pasungan Integralistik" UNISIA, Jurnal Ilmu dan Kebudayaan, No 34/XIX/1997, hal 42-51. 
maka barisan pengkritik Supomo telah bertambah.

Sebetulnya tulisan ini dimaksudkan sebagai tanggapan atas tulisan Kotan Y Stefanus, tetapi karena kritik terhadap Supomo dan tanggapan atasnya berkaitan erat dengan tulisan Kotan $Y$ Stefanus maka untuk memperoleh hal-hal itu diuraikan juga gagasan Supomo dalam tulisan ini.

\section{Cita negara Integralistik menurut Supomo}

Cita negara integralistik pertama kali dikemukakan oleh Prof. Mr. Dr. Supomo dalam pidatonya di BPUPKI tanggal 31 Mei 1945". Sebelum mengemukakan pendapatnya sendiri, terlebih dulu diuraikan adanya 3 aliran pikiran tentang negara yaitu teori individualistis yang diajarkan oleh Thomas Hobbes, John Locke, J.J Rousseau, dll, teori "golongan" yang diajarkan Marx, Engels dan Lenin dan teori Integralistik yang diajarkan Spinoza, Adam Muller, Hegel dil.

'Teori Integralistik yang diajukan oleh

Supomo tergambar dari kalimat-kalimat pidatonya sebagai berikut:

Jika kita hendak mendirikan negara yang sesuai dengan keistimewaan sifat dan corak masyarakat Indonesia, maka negara kita harus berdasar atas aliran pikiran [Staatsidee] negara yang integralistik yang mengatasi seluruh golongan-golonganya dalam lapangan apapun.

Menurut aliran pikiran ini, Kepala Negara dan badan-badan Pemerintah lain harus bersifat pemimpin yang sejati. penunjuk jalan ke arah cita-cita luhur yang diidam-idamkan oleh rakyat. Negara harus bersifat "badan penyelenggara" badan pencipta hukum yang timbul dari hati-sanubari rakyat seluruhnya. Dalam pengertian ini, menurut teori ini yang sesuai dengan semangat Indonesia yang asli, negara tidak lain ialah seluruh masyarakat atau seluruh rakyat Indonesia sebagai persatuan yang teratur dan tersusun ${ }^{12}$

Kemudian dia menghubungkan cita negara Integralistik dengan negara nasional dan totaliter:

Saya mupakat dengan pendirian yang hendak mendirikan negara nasional yang bersatu dalam arti totaliter, seperti yang saya uraikan tadi, yaitu negara yang tidak akan mempersatukan diri dengan golongan yang terbesar, akan tetapi yang mengatasi segala golongan dan akan mengindahkan dan menghormati keistimewaan dari segala golongan yang besar maupun golongan yang kecir ${ }^{3-}$

Jadi dalam negara totaliter atau integralistik, negara akan ingat kepada segala keadaan, hukum, negara akan memperhatikan segala keistimewaan dari golongan-golongan yang bermacammacam adanya di tanah-air kita ${ }^{14}$

Dan pada akhir pidatonya dia meringkaskan pendapatnya:

Sekian saja Paduka Tuan, tentang dasar-dasar yang hendaknya dipakai untuk mendirikan Negara Indonesia Merdeka. Atas dasar pengertian negara sebagai persatuan bangsa Indonesia yang tersusun atas sistem huhum yang bersifat Integralistik tadi, dimana negara akan berwujud dan bertindak sebagai penyelenggara negara keinsyafan keadilan rakyat seluruhnya, maka kita dapat melaksanakan Negara Indonesia yang bersatu dan adil, seperti sudah termuat dalam Panca Dharma, pasal 2, yang berbunyi: "Kita mendirikan negara hanya bisa termuat dalam Panca Dharma,

".Muhamad Yamin, Naskah Persiapan UUD 1945, Djakarta, Bukit Siguntang, Tjetakan kedua, 1971, hal 109-

${ }^{12}$, Ibid, HAL 113/114

${ }^{13} \mathrm{Jbid}$, hal. 117

${ }^{14} /$ bid, hal. 118 
Topik: Demokrasi Indonesia dan Citanegara Integralistik, Arifin, SS. Tambunan

pasal 2, yang berbunyi : "Kita mendirikan negara hanya bisa adil, jikalau negara itu menyelenggarakan rasa keadilan rakyat dan menuntun rakyat kepada cita-cita luhur, menurut aliran zaman. Negara Indonesia yang berdasar atas semangat kebudayaan Indonesia yang asli, dengan sendirinya akan bersifat negara Asia Timur Raya. Dan negara Indonesia yang tementuk atas aliran pikiran persatuan yang saya uraikan tadi, pun akan dapat menjalankan dharmanya [kewajibanya] dengan semestinya sebagai anggota dari pada kekeluargaan Asia Timur Raya ${ }^{15}$

\section{Kritik Terhadap Supomo.}

Sebagaimana telah dikemukakan kritik paling tajam dikemukakan oleh Marsillam Simanjuntak dan Daniel Dhakidae. Pendapat mereka mengandung tuduhan berat disertai requisitor yang menuntut hukuman mati terhadap cita negara integratistik.

Inti pendapat Marsilam Simanjuntak dapat diketahui dari kesimpulan yang dirangkumnya dalam Bab Penutup dari bukunya terutama dalam kalimat yang berbunyi "Aliran pikiran negara integralistik bila hendak dilanjutkan dalam pengertian yang diberikan Supommo itu, akan membawa akibat yang serius terhadap asas kedaulatan rakyat dan sistem demokrasi, berupa totaliterisme sebagai bentuk keluaranya"

Daniel Dhakidae mengemukakan bahwa Supomo tidak pernah mampu memecahkan beberapa problem teoretik, politik, konstitusional yang' dihadapinya dengán konsep "integralistik". Karena pantas dan bisa dipahami bahwa konsep negara "integralistik" memang patah dan gugur sebelum berkembang. Daniel membahas hubungan cita negara (staatside) dengan norma dasar (Grundnorm) : cita negara diperlukan untuk memungkinkan kehadiran norma dasar. Menurutnya citanegara inte- gralistik adalah nama janggal untuk suatu konsep lama yang pada dasarnya merupakan konsep liberian dengan nama asli corporatisme dan secara sempurna dipraktekkan di lingkungan gereja Katolik. Karena dalam perkembangan selanjutnya dalam ilmu politik disebut organic state maka dalam pemakaianya negara korporatis sering tertukar dengan negara organik. Cita negara korporatis tersebut hidup dan terwujud paling tidak dalam tiga orang yaitu Mussolini, Franco dan Hitier. Menurut Daniel, Supomo mengambil alih pengertian negara korporatis/organis karena itu cocok untuk Indonesia. Dan ketakutan kepada Jepang menyebabkan Supomo mengambil sesuatu yang mirip-mirip dengan yang berlaku di Jepang yaitu persatuan dan kekeluargaan yang dikatakan sangat sesuai dengan corak masyarakat Indonesia. Supomo menyebutnya sebagai sistim totaliter dengan pengertian yang tidak kurang anehnya. Pengertian ini menurut Daniel bukan saja aneh secara teoretik, tetapi anakronik secara historis. Kemudian Supomo tidak bisa menjelaskan bagaimana supremasi masyarakat (kedaulatan rakyat) berhubungan dengan negara yang berdiri di atas segala-galanya (kedaulatan negara).

Juga dia pertanyakan bagaimana menjelaskan Pancasila sebagai suatu Grundnorm telah menghasilkan dan membenarkan tiga negara yang berbeda dilihat dari konstitutinya yang bertentangan satu sama lain, yaitu UUD 1945, Konstitusi RIS 1949 dan UUDS 1950. Citanegara yang bagaimanakah yang mungkin didukung oleh norma-norma dasar seperti itu? Daniel berkesimpulan bahwa Marsilam secara teori kolegal berhasil menolak dan menelanjangi Supomo, membongkar kekacauan logikanya, mematahkan anakronisme historisnya dan cacat konstitusionalnya.

15. ibid hal $120 / 121$ 
Topik: Demokrasi Indonesia dan Citanegara Integralistik, Arifin, SS. Tambunan

Selain itu perdebatan yang terjadi di BPUPKI antara Supomo dan Sukarno di satu pihak dan Moh. Hatta, Sukiman, Moh. Yamin dan Liem Koen Hian di lain pihak dijadikan bukti bahwa cita negara integralistik tidak diterima BPUPKI. ${ }^{16}$

\section{Tanggapan atas kritik terhadap Supomo}

Di atas telah dikatakan bahwa kritik Marsillam dan Daniel telah mendapat tanggapan dari para penùlis Indonesia. Inti pendapat mereka bahwa tidaklah benar bahwa BPUPKI menolak citanegara integralistik yang diusulkan Supomo. Jadi, BPUPKI sama sekaii tidak menolak citanegara integralistik.

Menurut penulis, kritik yang sedemikian tajam itu yang ditujukan kepada perumus utama UUD 1945 adalah kurang fair: Kiranya masalah ini perlu dijemihakan:

Pertama-tama perlu diperhatikan beberapa hal sebagai berikut :

- bahwa pidatonya itu bukanlah pidato ilmiah sehingga kurảng tepat untuk meninjaunya dari segi ilmiah semata-mata;

- bahwa pidatonya itu merupakan pidato politis sehingga harus ditinjau dari kaca mata politis

- bahwa sebagai seorang pakar dalam hukum adat, Supomo mengetahui betul tentang kehidupan dan kebudayaan masyarakat Indonesia.

- bahwa bahasa Indonesia yang digunakan dalam BPUPKI masih dalam tahap awal perkembangan dan belum terdapat istilah baku mengenai katakata yang berasal dari bahasa asing, jadi masih belum seperti bahasa Indonesia yang dikenal sekarang ini.

Marsillam Simanjuntak dan Daniel Dhakidae sendiri memahami bahwa sidang-sidang BPUPKI berlangsung di bawah pengawasan yang ketat dari Jepang, malahan di dalam tubuh BPUPKI sendiri terdapat 8 (delapan) anggota barngsa Jepang termasuk seorang Wakil Ketua BPUPKI. Dapatlah dimengerti kalau para anggotanya menjaga agar tidak menimbulkan kemarahan Jepang. Oleh karena itu untuk dapat memahami pidato Supomo, harus dapat dibedakan mana yang dimaksudkan hanya sebagai bunga-bunga saja untuk "mengelus" perasaan orang Jepang dan mana yang betul-betı'l merupakan esensi dari pidatonya. Termasuk sebagai bunga-bunga adalah penyebutan negara Jerman-Hitler (sekutu Jepang), hubungan keluarga Kaisar Jepang dengan rakyat Jepang, negaranegara Asia Timur Raya (konsepsi Jepang), dan hal-hal yang berhubungan erat denganya. Jadi, kalau bunga-bunga itu dianggap tidak ada maka sisanya mengandung pemikiran sebenarnya dari Supomo. Esensi pidatonya termuat dalam akhir pidato Supomo. Semua yang sudah biasa hidup di lingkungan masyarakat Jawa maklum akan hal itu, dan temyata para anggota BPUPKI orang Indonesia juga memahaminya.

Tidak mudah untuk menemukan istilah yang paling tepat dalam bahasa Indonesia, inilah munckin yang menyebabkan Supomo menciptakan istilahnya sendiri seperti integralistik dan totaliter. Kata ajektif ini hendaknya jangan dicampur-adukkan dengan kata benda, integralistik tidak sama dengan integralisme, dan totaliter tidaklah sama dengan totaliterisme. Karena merupakan istilah yaiig sama sekaij baru maka seharusnya diartikan menurut pengertian yang diberikan oleh penciptanya, dan apa yang dimaksud.dengan kedua istilah ciptaanya sendiri itu secara jelas diuraikan oleh Supomo dalam pidatonya.

Dari uraian mereka di BPUPKI secara jelas nampak bahwa Supomo dan juga Bung Karno dan Bung Hatta tidak menganut ajaran otonomi individu yang bermula 
di Barat kemudian berkembang ke bidang filsafat yang terwujud dalam filsafat individualisme, ke bidang ekonomi yang melahirkan ajaran laissez faire, ke bidang hukum yang melahirkan ajaran kebebasan mengadakan kontrak, hak milik individu dan kebebasan individu, ke bidang politik yang terwujud dalam ajaran yang mengatakan bahwa legitimasi kekuasaan politik didasarkan pada people's poweryang kemudian menjelma dalam ajaran tentang kontrak sosial dan hak politik warga masyarakat ${ }^{7}$. Jadi, tidak ada perbedaan pendapat tentang pengertian hak-hak manusia, perdebatan yang terjadi antara Bung Karno/Supomo dan Bung Hatta adalah mengenai penempatan hak-hak manusia dalam UUD 1945. Perdebatan itu bukan mengenai cita negara integralistik. Cita negara integralistik tidak menentang hak-hak manusia. ${ }^{8}$

\section{Bukan hal baru}

$\mathrm{Hal}-\mathrm{hal}$ yang dikemukakan oleh Supomo di BPUPKI sebetulnya bukanlah barang yang baru karena sudah terdapat, setidak-tidaknya benih-benihnya, dalam tulisan dan pidato-pidato sebelumnya terutama dalam pidato penerimaanya sebagai Guru Besar dalam Hukum Adat pada tahun 1941 di Recht Hoge School (Sekolah Tinggi Hukum] di Jakarta ${ }^{19}$. Dikatakan bahwa berbeda dengan di Barat maka bagi bangsa Indonesia individu tidak dapat terlepas dari masyarakat, sehingga hak dan kewajiban yang dimilikinya berhubungan dengan fungsinya dalam masyarakat. Jadi, hak-hak warga itu pada hakekatnya merupakan gemeenschapssechten [hak-hak komuniti], karena dihubungkan dengan fungsi warga yang bersangkutan dalam kehidupan masyarakatnya. Hal ini sesuai dengan pandangan bangsa Asia-Afrika terhadap hakhak manusia yang selalu dibingkai dengan kewajiban-kewajibanya dalam masyara- $k^{t^{20}}$. Dalam pidatonya itu secara jelas terlihat pendirian Supomo bahwa individu terintegrasi dalam masyarakat. "Persatuan dan kesatuan masyarakat yang dikemukakan dalam BPUPKI pada tahun 1945 tidak tergambar dalam pidatonya pada tahun 1941 itu. Sebagaimana juga halnya dengan Bung Kamo dan Bung Hatta maka Supomo yakin betul bahwa kunci keberhasilan mendirikan negara Indonesia Merdeka terletak pada persatuan dan kesatuan bangsa tanpa menghilangkan eksistensi suku-suku bangsa dan golongan-golongan yang ada dalam tubuh bangsa Indonesia.

Dengan demikian Bung Karno, Bung Hatta dan Supomo menghendaki suatu pemikiran yany dinamis mengenai negara dari konstitusi. Kehidupan negara merupakan suatu proses integrasi yang kontinu, perjuangan untuk merealisasikan Sumpah Pe-

${ }^{17} . T$ Koopmans, Vergelijkend Publickrecht Deventer, Kluwer, 1978, hal 200.

${ }^{18}$ A.S.S. Tambunan, Persoalan-persoalan Hak-Hak Manusia dan UUD 1945, Suatu tinjauan dari sudut hukum Tata Negara Jakarta, STHM, 1996, hal 45-48.

19. Prof. Mr. Dr. Supomo Verhounding van individu en gemeenschaap in het adatrecht, yang terjemahanya kemudian diterbitkan dengan judul Hubungan Individu dan masyarakat dalam Hukum Adat, Pradnya Paramita, 1978.

${ }^{20}$ Untuk pandangan bangsa Afrika baca African Charter Human and Right 1981 dalam Paul Sieghart, The Lawful Right of Mankind, An function to the International Legal Code of Human Rights, 1981 dalam Paul Sieghart, The Lawful Rights of Mànkind, An Introduction to the International Legal Code of Human Rights, Oxford University Press paperback, 1986, hal 231-237. Untuk pandangan bangsa Asia baca Yogesh Atal \& Ralph Pieres [eds] Kritik Asia terhadap Pembangunan, Jakarta Yayasan IImu-ilmu Sosial, 1980; juga baca Kuntjoro Purbopranoto 16 Juni 1994. 
Topik: Demokrasi Indonesia dan Citanegara Integralistik, Arifin, SS. Tambunan

muda 1928 yaitu satu nusa, satu bangsa dan satu bahasa Indonesia tidak sekaili jadi. Jadi, masalah integrasi negara dan bangsa Indonesia biasa merupakan masalah yang statis tetapi harus secara terusmenerus direalisasikan. ${ }^{21}$ Dengan begitu mereka secara tidak langsung menyetujui teori integrasi dari Rudolf Smend dan S.W. Couwenberg ${ }^{22}$. Rudolf Smend mengatakan bahwa realisasi integrasi negara merupakan proses yang terus-menerus melalui berbagai lembaga, prosedur dan lambang. Dan S.W. Couwenberg mengatakan bahwa hukum tata negara sebagaimana berfungsi dalam praktek sebenamya merupakan suatu permanent politiek juridisch tranformatie en integratieproces. (proses transformasi dan integrasi politis-yuridis yang permanen)..$^{23}$ Dari kalimat-kalimat yang terdapat dalam Pembukaan UUD 1945 dan Penjelasannya secara jelas nampak bahwa kehidupan negara dan bangsa di bawah naungan UUD 1945 merupakan suatu proses integrasi dinamis yang terus-menerus.

Kalau diteliti lebih lanjut, ada kemungkinan bahwa Marsillam Simanjuntak dan Daniel Dhakidae terpengaruh oleh pendapat J.H.A. Logemann yang sebelumnya juga telah melancarkan kritik atas Supomo ${ }^{24}$. Dia mengatakan bahwa cita negara integralistik adalah cita negara organis dari masyarakat desa, dan adalah sangat tidak mungkin untuk memindahkan struktur desa menjadi struktur negara modem.

Juga dikemukakah bahwa pendapat Supomo dekat dengan aliran nasional sosialisme (Nazi), bahwa kedudukan pimpinan negara terlalu kuat dan bahwa kedaulatan rakyat tidak mendapat tempat dalam pemikiran Supomo. Jelas sekali kelihatan hubungan pemikiran Logemann dengan pemilkiran Marsillam Simanjuntak dan Daniel Dhakidae.

\section{Tentang Hegel, Spinoza dan Adam Muller}

Selanjutnya Supomo melalui pidatonya di BPUPKI dar pidato-pidato sebelumnya telah membuktikan bahwa dia mengetahui betul tentang filsafat Barat seperti yang diajarkan oleh Hegel, Spinoza dan Adam Muller, sehingga kritik yang mengatakan, seolah-olah Supomo tidak mengerti ajaranajaran itu adalah tidak pada tempatnya. Abdul Hamid Saleh Attamimi telah memberikan uraian yang panjang lebar mengenai masalah ini.. ${ }^{25}$ Tetapi penulis ingin menambahnya sebagai beriktit ini.

Pertama-tama mengenai Hegel. Georg Willhelm friedriech Hegel adalah salah seorang filsuf terbesar yang pemah hidup dan dalam tulisan-tulisanya menyinggung masalah negara dan hukum. Dia menentang pemikiran kaum liberal yang berkembang pada waktu itu, yaitu pemikiran tentang kebebasan incividu dan keyakinan akan

21 - Juwono Sudarsono, "Perkembangan Politik dalam Pembangunan jangka Panjang 25 Tahun Kedua: Perspektif Intemasionar", Analisis CSIS Thn XIX No.4 Juli-Agustus 1990.

22 - Dr.S.W.Couwenberg De Omsteen Staat, Alphen a/d Rijn Uitgeverij, 1974, hal. 21 et.seq.

${ }^{23}$.S.W.couwenberg. Westers Staatscrecht als emancipatieproces, Alphen aan den Rija, Samson Uitgeverijk, 1977 hal 13.

${ }^{24}$ - J. H. A. Logernann "Indonesie's terugkeer tot de Grondwet van 1945" dalam Bridjen tot de taal-,land-, end volkenkunde, 's Gravenhage, Martinus Nijhoff, 1959 dan Keterangan-keterangan Baru tentang terjadinya Undang-Undang Dasar Indonesia 1945 terjemahan Dardji Darnioditiardjo, judul asli:Niewu gege:/ens over het onstaan van de Indonesische grondwet van 1945), Jakarta, Aries Lima, catakan ketiga, 1983.

25. A. Hamid S. Attamini, Op cit, hal. 57-83. 
kemampuan setiap orang untuk menentukan dan merealisasi sendiri kepentingannya. Hegel mengatakan bahwa kaum liberal hendak merusak hubungan-hubungan yang ada dalam masyarakat. Akibat pemikiran ini manusia akan lepas kendali dan demi kebebasan dia tidak mengakui lagi patokan/pedoman yang berlaku sebelumnya dalam kehidupan masyarakat. Selanjutnya hal ini akan merendahkan negara menjadi hanya untuk individu saja, negara bertugas hanya untuk mengurus agar kepentingan seorang tidak bertabrakan dengan kepentingän orang lain, dan tidak melindungi hak milik perorangan saija ${ }^{26}$. Dia mengatakan bahwa perkembangan historis dáripada pengertian negara menghasilkan dua hal yang bertentangan yaitu pertama bahwa negara memiliki kedaulatan yang berasal dari Tuhan dan yang menjelma dalam diri raja, dan kedua bahwa negara merupakan suatu perjanjian rasional dari rakyat yang berdaulat. Hegel meningkatkan kedua hal yang bertentangan ini dan kematian dijadikan suatu sintesa yaitu pengertian negaŕa sebagai kerajàan konstitusional di mana raja dan rakyat bekerja sama ${ }^{27}$ Individu dan negara secara intrinsic adalah satu, negara adalah suatu bagian atau aspek yang esensial dari kodrat manusia, individu secara konsepsiorial tidak dapat dimengerti tanpa negara. Man finds hid perfection in the state ${ }^{28}$

Hegel mengatakan bahwa lingkungan kéhidupan etis [ethical life] manusia terdiri dari tiga jenis atau tingkatan hubungan manusia yang berbeda tetapi menyatu șecara dialektis yaitu keluarga, masyarakat [burgelijke Geseelschaft, civil society] dan negara. Ketiga jenis/ tingkatan hubungan manusia itu saling berhubungan dan saling memerlukan [interpedent] dan menurut Hegel manuisia yang tertinggi adalah negara ${ }^{29}$

Hegel very resolutely refuses to allow the state to devour civil society, his vision is that of the absolute state'sut not of total state ${ }^{30}$.

t:

Prof D H.M. Metiwissen yang khusus mendalami ajaran Hegel dalam hubungan ini mengemukakan bahwa cita negara dari Hegel dikaitkan dengan kebebasan.. ${ }^{31}$ Guru besar ini berkesimpulan bahwa citanegara Hegel sama sekali tidak menuju ke negara toialiter dan tidak ada hubunganya dengan totaliterisme.Oleh karena itu dia tidak dapat mengerti mengapa pengertian Hegel mengenai negara selalu ditafsirkan secara negatif. Keluhan yang serupa juga diutarakan oleh A Rachman Zainuddin ${ }^{32}$

Jadi, Hegel sama sekali tidak menghendaki timbulnya totaliterisme, dia adalah penganut negara monarki konstitusional. Agak mengherankan bahwa kemudian ada yarig menghubung-hubungkan teori Hegel dengan Mussolini dan Hitler. Sama halnya kalau ada yang menghubungkan teori Rousseau dengan prinsip Fuhler, sebab bukankah dapat dikatakan bahwa adanya Fuhrer didasarkan pada volonte de tous

26. C.W van der Pot, Handbock van het Nederlandsc Staatsrecht, Zwolle, W.E.J. Tjeenk Willink, 1983, hal 40.

27 J.J. Von Schmid, Het denken over staat en recht in de negentiende eeuw, Haarlem De Erveen F bohn NV 2 de druk, 1948, hal 88; juga R.N. Berki The History of Political Thought, A Short introduction, Tototwa NJ Rowman and Littlefield, 1977, hal174.
28. R.N Berki, Loc. Cit
$29 \mathrm{lbid}$, hal.176-177.
${ }^{30}$ R.N Berki Op Cit hal 178.
31. D.H.M. Meuwissen "Staàt Vrijheid", Civis Mundi, Tijdschrift voor Bügerscapsvorming 21, Jaargang, Juli, 1982 hal 128.

32. A. Rachamn Zainuddin.,Op. Cit. 
dari rakyat Jerman sehingga dapat dikatakan bahwa negara fasis Jerman-Hitler diRosseau dengan negara komunis yang menekankan pada kesamaan (equality) sesuai dengan yang diajarkan oleh Rousseau. $\mathrm{He}$ gel dan juga Rosseau tidak mungkin menghendaki, ajaranya dijadikan landasan dari negara-negara fasis Jerman-Hitler, ItaliaMussolini dan Spanyol-Franco atau Soviet Uni/RRC.

Prof G.A van der Wal berdasarkan penelitianya atas tulisan -tulisan Benedict Spinoza menyimpulkan bahwa kebebasan adalah kategori normatif yang sentral dalam filsafat Spinoza. Menurut Spinoza tujuan dasar dari setiap orde [pemerintahan] adalah menjamin kenyamanan dan kebebasan warga masyarakat dan dia menguraikan bagaimana seharusnya pemerintahan diatur untuk mencegah timbulnya tirani dan penindasan sehingga kenyamanan serta kebebasan para warga masyarakat terjamin. Untuk dapat mencapaianya, menurut Spinoza bentuk pemerintahan yang terbaik adalah Demokrasi. ${ }^{33}$

Jadi, baik Hegel maupun Spinoza berusaha mencari suatu sistem yang dapat menjamin kenyamanan dan kebebasan para warga masyarakat dan mencegah tindakan semena-mena dari penguasa. Peranan negara adalah untuk mengintegrasikan dan menyeimbangkan semua keinginan dan kepentingan para warga masyarakat sedemikian rupa agar tujuan negara tersebut di atas dapat tercapai.

Atau seperti yang dituturkan oleh Ahmad Subardjo :

Adam Muller, Hegel serta lainya telah mengemukakan teori negara persatuan. Menurut teori ini, negara semata-mata tidak menjamin kepentingan individu, kepentingan satu kelas atau kelompok, bagaimanapun besar atau kuatnya kelompok atau kelompok itu. Tetapi negara memberikan jaminan atas kepentingan masyarakat secara keseluruhan, sebagai satu kesatuan. Struktur sosial dari negara disatukan, seluruh kelas, bagian-bagian serta semua anggota masyarakat secara erat dirangkaikan sebagai satu kesatuan yang organis ${ }^{34}$.

Menurut Prot. Dr J.J. von Schmid ciri khas dari Adam Muller adalah bahwa dia selalu hendak menjembatani perbedaan dan pertentangan dengan berusaha untuk menyerasikan dan menyeimbangkan. Oleh karena itu dalam ilmu negara dia melihat fakta bahwa bangunan negara terdiri dari kekuatan-kekuatan yang bersifat organis, Juga bahwa segala kekuatan dan kekuasaan di dalam negara tidak hanya bersumber dari satu titik yang berdaulat. ${ }^{35}$ Adam Muller melihat bangunan negara dari segi masyarakat dan mengatakan bahwa negara merupakan suatu susunan yang diwujudkan oleh kekuatan-kekuatan yang mandiri dan saling berdampingan atau berhadapan. Dengan demikian Adam Muller menolak konstruksi bangunan negara yang didasarkan aliran akal atau hukum alam yang selalu berpangkal-tolak dari individualisme dan pemikiran kedaulatan.

Berdasarkan hal-hal yang diuraikan di atas, dapat dimengerti rumusan-rumusan yang terdapat dalam UUD 1945 yang menyangkut kedaulatan. Pengertian kedaulatan rakyat dalam UUD 1945 adalah berbeda dengan pengertian kedaulatan rakyat di Barat. UUD 1945 menganut ajaran kedaulatan rakyat yang terpadu dengan ajaran kedaulatan Tuhan, kedaulatan

33. G.A. van der Wal "Spinoza over staat, vijheid en demokratie" Civis Mundi, Tijdschrift voor Burgerrscahpsvorming.

34. Ahmad Subardjo Djojoadisurjo, Kesadaran Nasional, Otobiografi, Jakarta, Gunung Agung, 1978, hal 279-280.

${ }_{35}$ J.J. van Schmid. Op. Cit. hal 57 
negara dan kedaulatan hukum ${ }^{36}$. Oleh karena itu kritik Marsillam Simanjuntak dan Daniel Dhakidae tidak mengenai sasaran karena mereka menggunakan pengertian tentang kedaulatan rakyat yang didasarkan kepada Rousseau. Sebagaimana diketahui ajaran kedaulatan dari Rosseau merupakan reaksi terhadap ajaran kedaulatan Tuhan dan kedaulatan raja sehingga ajarannya itu tidak mengandung hal-hal yang berbau raja atau Tuhan $^{37}$. Selain itu rupa-rupanya Marsilam dan Daniel tidak mengikuti perdebatan yang timbul di Barat mengenai pengertian kedaulatan dari Rosseau ${ }^{38}$ sehingga tidak mengetahui timbulnya pendapat bahwa pengertian itu menurut para pakar hukum tata negara sudah kadaluwarsa dan tidak tidak terpakai lagi dalam hukum tata negara. ${ }^{39}$

\section{Pancasila melahirkan tiga negara yang berbeda?}

Kritik Daniel Dhakidae mengenai bagaimana dapat dijelaskan bahwa Pancasila telah melahirkan tiga negara yang berbeda satu sama lain merupakan masalah yang sangat prinsipil sekali sehingga perlu ditanggapi. Kritik ini mengandung dua segi yaitu segi politik dan segi hukum. Dari segi politik dapat dikatakan bahwa pada tahun 1949 Indonesia maupun Belanda mendapat tekanan dari PBB terutama dari Amerika Serikat supaya melakukan perundingan. Terjadilah suatu kompromi dan terbentuklah Negara Indonesia Serikat di bawah Ratu Belanda dengan Konstitusinya. Namun ternyata menurut catatan George Mc T Kahin, Belanda dalam melakukan komromi tadi mempunyai maksud-maksud tertentu.

[the Dutch Government] was wore concerbed with promoting a strategy of devide and rule, calculated to eventuate order which they could inndirectly control than in estabfishing a federal system honestly dedicated to Indonesia's very real need lola poitical decentraliztion consistent with basic geographic, economic, and cultural factors ${ }^{40}$

Di lain pihak Indonesia dalam melakukan kompromi itu telap melanjutkan perjuangannya. supaya terlepas sama sekali dari ikatan dengan Belanda. Pada tanggal 17 Agustus 1950 Indonesia kembali menjadi negara kesatuan yang terlepas dari ikatan dengan Belanda tetapi dengan UUDS 1950 yang mengikuti sistem yang berbeda dari UUD 1945. Dari perdebatan di Konstittiante secara jelas dapat diketahui bahwa mayoritas menghendaki kembali ke UUD 1945 , tetapi karena persyaratan mayoritas

${ }^{36 .}$.Hazairin, Demokrasi Pantjasila, Djakarta, Tinta Mas, 1970 hal 32 et.seq: juga Ismail Sunny, Mekanisme Demokrasi Pancasila Jakarta, Aksara Barum 1978, hal 8: Wirjono Prodjodikuro, Asaz-asas Hukum Tata Negara Indonesia, Jakarta Dian Rakyat, 1980, hal 6.

${ }^{37}$. Ajaran Rousseau kemudian masuk UUD Perancis, dan kalau UUD ini disimak maka tidak akan dapat diketemukan suatu katapun mengenai Tuhan. Hal ini adalah berbeda dengan UUD Amerika Serikat, UUD Jerman, UUD Republik Irlandia dan UUD 1945. Mengenai pengertian kedaulatan menurut UUD 1945 baca selanjutnya A.S.S Tambunan "Kedaulatan Rakyat menurut UUD 1945" dalam majalah Era Hukum, Jurnal Ilmiah Hukum, No. 10/Th.3/Oktober 1996.

38. A.S.S. Tambunan, Konsepsi Fungsi Sosial Politik ABRI dalam Nugroho Notosusanto [ed] Pejuang dan Prajurit, Konsepsi dan implementasi Dwifungsi ABRI, Jakarta, Pustaka Sinar Harapan, Cet Ketiga, 1991, hal 198-201.

39. Staatsrechttelijk Symposium, Object Methode van de Staatschetwetenschaap, Nijmegen, 14 Desember 1973.

${ }^{40}$. George Mc T Kahin, "Indonesia" dalam George Mc T Kahin [ed] Major Government of 
Topik: Demokrasi Indonesiạ dan Citanegara Integralistik, Àrifin, SS. Tambunan

khusus tidak tercapai kendatipun pemungutan suara sampai dua kali diulang maka akhimya lahir Dekrit Presiden tanggal 5 Juli 1959.

Dari sudut hukum dapat dikemukakan hal-hal berikut. Memang rintisan Pancasila terdapat dalam Pembukaan/Mukadimah dari UUD 1945, Konstitusi RIS 1949 dari UUDS 1950 sehingga menimbulkan kesan sebagaimana diuraikan oleh Daniel Dhakidae dalam tulisanya. Tetapi kalau diteliti secara saksama akan dapat diketahui bahwa hanya UUD 1945 saja yang secara tegas menyatakan bahwa batang tubuh UUD dikuasai oleh pokok-pokok pikiran yang terdapat dalam Pembukaan. Karena ketentuan semacam itu tidak terdapat dalam kedua UUD yang lain maka dapat dikatakan bahwa Pancasila secara praktis hanya merupakan hiasan belaka karena tidak mempunyai pengaruh kepada batang tubuh UUD. Memang secara politis pada waktu itu selalu dikemukakan terutama oleh Bung Karno bahwa negara RI didasarkan pada Pancasila, tetapi secara yuridis konstitusional hanya UUD 1945 yang menyatakan demikian itu. Oleh karena itu tidak dapat dituduhkan bahwa Pancasila telah melahirkan tiga negara yang berbeda qua konstitusi dan sistem Politiknya. Kemudian Daniel Dhakidae beranggapan bahwa UUD 1945 mengikuti aiaran Hans Kelsen dengan Grundnorm-nya ${ }^{41}$ Anggapan ini tidak benar karena UUD 1945 bukan penganut aliran positivisme atau legisme $e^{42}$ Telah dikatakan bahwa UUD 1945 bukan hanya mengakui hukum yang tertulis saja tetapi juga hukum tidak tertulis, dan bahwa para perumus UUD 1945 berangkat dari pengertian hukum tata negara yang luas dan dinamis.

Perdebatan BPUPKI telah menjadi sejarah, dan bahwa hasil karyanya merupakan gabungan dari pokok-pokok pendapat yang telah dikemukakan. Pengaruh pemikiran Supomo secara jelas tampak da- lam UUD 1945 terutama dalam Pasal-pasal 1, 2, 29. 31, 32 dan 34, dan barang tentu juga dalam Penjelasan UUD 1945 yang merupakan hasil rumusanya sendiri. Untuk menghormati Supomo Sidang Umum MPR tahun 1993 telah mengangkat kembali istilah "integralistik" dan menegaskanya sebagai cita negara Republik Indonesia..$^{43}$

Kemudian ada satu hal yang luput baik dari perhatian Daniel Dhakidae maupun dari perhatian Marsillam Simanjuntak yaitu disebutnya Panca Dharma oleh Supomo pada akhir pidatonya. Oleh karena Panca Dharma adalah asas-asas dari Taman Siswa (kelima asas itu adalah kodrat alam, kebudayaan, kemerdekaan, kebangsaan dan kemanusiaan), maka timbul dugaan bahwa Supomo terpengaruh oleh ajaran Ki Hadjar Dewantara.44 Dugaan ini diperkuat oleh rumusan yang terdapat dalam Penjelasan UUD 1945 yang dibuat oleh Supomo mengenai semangat kekeluargaan, kepemimpinan, kebudayaan. Rumusan itu sama

41. A.S.S. Tambunan, "Teori Hans Kelsen dihubungkan dengan Hukum Positif Indonesia" Jakarta [tidak dipublikasikan] 1996.

${ }^{42}$ A.S.S. Tambunan, "Teori-Teori Filsafat Hukum yang Terkandung dalam UUD 1945 Era Hukum Jurnal IImiah Hukum , No 12 Tahun ke -3, April 1977.

43. Bab II huruf $\mathrm{G}$. Kaidah Penuntun No 5: Pandangan Integralistik bangsa Indonesia dan paham kekeluargaan yang berakar pada nilai-nilai budaya bangsa yang dijadikan kesepakatan dalam penyusunan UUD 1945 harus dijadikan paham kebangsaan Indonesia untuk memperkukuh persatuan dan kesatuan bangsa dalam negara kesatuan.

${ }^{44}$ Supomo pernah berpidato dalam Rapat Besar ke -5 Taman Siswa di Yogyakarta pada tanggal 7-11 Juli 1937 [Judul pidatonya Hidoep Hoekoem bangsa Indonesia MataramYogya, Majelis Peroesahaan Kitab Taman Siswa, 1937] 
atau setidak-tidaknya mirip betul dengan rumusan Ki Hadjar Dewantara 45. Taman Siswa-yang didirikan Ki Hadjar Dewantara mencita-citakan demokrasi Indonesia dan bukan penganut otorianisme, diktatur atau totaliterisme. Jadi, Supomo tidak mungkin mencita-citakan suatu negara seperti Jerman-Hitler dan Jepangnya Hirohito.

\section{Kritik Kotan Y. Stefanus dan tanggapan terhadapnya}

Dengan mengatakan bahwa teori integralistik telah patah dan gugur sebelum berkembang maka Kotan Y. Stefanus mengikuti pendapat Marsillam dan Daniel. Sama dengan Marsillam dan Daniel, dia mendasarkan pendapatnya pada kedaulatan rakyat. Karena tidak menguraikannya lebih lanjut maka dapat diartikan bahwa dia menganut ajaran kedaulatan rakyat dari Rosseau. Juga dia mengajukan konstruksi paradigma dari Thomas Kuhn. Ruparupanya dilupakan bahwa penggunaan konsep paradigma dimaksudkan untuk ilmu pengetahuan alam khususnya ilmu Fisika ${ }^{46}$ Teori Kuhn tidak berlaku bagi ilmu-ilmu budaya dan sosial. Setiap pemikiran mengenai masalah-masalah hukum dipengaruhi oleh pandangan hidup, politik, ideologi, emosi dari orang yang bersangkutan ${ }^{47}$ Sebagai contoh adalah teori tentang hak-hak manusia yang begitu banyak dan hingga sekarang masih berlangsung pertentangan antara kaum universalis (yang menganggap teorinya berlaku secara universal) dan kaum relativis yang menentangnya..$^{48}$ Kemudian dia mengemukakan bahwa Supomo mengenyampingkan makna demokrasi tanpa memberikan uraian teori demokrasi mana yang dianutnya.

Dengan mengemukakan bahwa hakekat negara adalah organisasi kekuasaan, dapat disimpulkan bahwa Kotan Y. Ste- fanus menganut ajaran J.H.A. Logemann ${ }^{49}$ yang mempunyai pandangan yang sempit dan statis mengenai negara dan konstitusi. UUD 1945 mempunyai pandangan yang luas dan dinamis mengenai negara dan konstitusi. ${ }^{50}$ Sebagaimana telah dikatakan sebelumnya, pendirian dari Bapak Pendiri Negara RI dan Perumus UUD 1945 adalah sesuai dengan teori integrasi dari Rudolf Smend dan S.W. Couwenberg. Mereka menyadari betul bahwa karena tiadanya persatuan diantara suku-suku bangsa Indonesia maka Belanda berhasil secara mudah menancapkan kuku kolonialisme sampai waktu ratusan tahun lamanya. Para Bapak Pendiri Negara R.I. menyadari betul bahwa bangsa Indonesia perlu bersatu tanpa menghilangkan eksistensi golongan-golongan dan suku-suku bangsa yang ada. Mereka menyadari betul bahwa terdapat banyak perbedaan dan pertentangan antara golongan-golongan dan suku-suku bangsa Indonesia. Perbedaan dan pertentangan itu tidak dapat dilebur menurut dialektikanya

45. Rumusan Ki Hadjar Dewantara mengenai kekeluargaan terurai dalam Ki Hadjar Dewantara, Yogyakarta Majelis Taman Siswa cet kedua 1977.

${ }^{46}$.Zenon Bankowiski, Revolutions in Law and Legal Thought Aberdeen, Aberdeen University Press, 1991, hal 176.

47. R.J.B. Bergamin, H.Th.J.F. van Maarseveen, H.F.H. Schonk-Swier, Decultuurstaat, Deventer, Kluwer, 296, hal: 1 , juga W. Friedmann, Legal Theory, London, Steven \& Sons, Edisi ke-4, 1960, hal 1.

48. A.S.S. Tambunan, Perlukah Suatu Ketetapan MPR mengenai HAM, STHM, 1997, hal 9 .

49 J.H.A. Logemann, Over the theorie vaan enn steligg staatsrecht, Djakarta, Penerbit Saksama, 1954, hal 72.

50. Dari penjelasanya UUD 1945 bersifat terbuka, ditekankan dalam pasal 32 UUD 45. 
Hegel tetapi dikompromikan dari diseimbangkan menurut dialektikanya Pierre Joseph Proudhon. ${ }^{51}$ Pendapat mereka tergambar dalam anak kalimat alinea kedua Pembukaan UUD 1945 "perjuangan pergerakan kemerdekaan Indonesia telah sampai kepada saat yang berbahagia" dan kalimatkalimat yang terdapat dalam Penjelasan tentang pokok-pokok pikiran dalam Pembukaan, yaitu bahwa dalam Pembukaan diterima aliran pengertian Negara Persatuan yang meliputi segenap bangsa Indonesia seluruhnya, dan bahwa Negara yang melindungi dan meliputi segenap bangsa seluruhnya. Berdasarkan, hal-hal itu semua penulis sependapat dengan M. Nasroen ${ }^{52}$ dan S.W. Couwenberg yaitu bahwa hakekat negara adalah kematian bersama dari suatu pergaulan hidup (the community) tekad perjuangan rakyat Indonesia untuk mengadakan negara, tetapi dengan catatan bahwa kemauan bersama itu adalah sebagai hasil proses integrasi yang terus menerus. $\mathrm{Pe}$ nulis berpendapat bahwa sistem kenegaraan hanya dapat dimengerti dari perkembangan dan pertumbuhanya, dan bahwa negara fenomena sejarah (historisch bepaald) sehingga negara dan hukum tata negara Indonesia dapat lebih mudah dipahami kalau dianggap sebagai suatu proses integrasi historis sosiologis. Jadi, kata kunci untuk hakekat negara $\mathrm{Rl}$ adalah kemauan bersama rakyat dan proses integrasi yang kontinu sebab tanpa itu tidak ada Negara RI untuk sekarang maupun waktu yang akan datang.

Kemudian Kotan Y. Stefanus mengatakan bahwa basis teori integralistik yang dikemukakan Supomo tidak memperhitungkan prospeknya dalam dimensi waktu yaitu dinamika masyarakat menuju masyarakat modern. Setelah mengetahui hal-hal yang diuraikan di atas maka. pendapatnya ini telah kehilangan dasar.

Selanjutnya dikatakan bahwa pandang- an Supomo tentang konsep Manunggaling Kawulo Gusti dalam kaitannya dengan paham integralistik adalah konsep yang sangat sempit dan konvensional karenaSupomo terlalu mengagung-agungkan persatuan dan kesatuan antara rakyat dan penguasa sehingga mengenyampingkan makna demokrasi yang sebenarnya merupakan hal yang esensial tak terpisahkan dari hakekat negara sebagai organisasi kekuasaan yang berkonstitusi. Sekarang akan dicoba dibahas apakah betul bahwa konsep itu sempit dan konvensional. Karena menyangkut falsafah tentang individu dan kehidupan bersama dalam masyarakat, memang agak sulit untuk menjelaskan konsep yang mempunyai pengertian mendalam itu hanya dalam beberapa kalimat saja. Hal itu sebenamya telah diungkapkan oleh Supomo datam pidatonya pada tahun 1941 tersebut diatas. Telah dikatakan bahwa Supomo terpengaruh oleh ajaran Ki Hadjar Dewantara. Ki Hadjar Dewantara mengartikannya sebagai persatuan diri dengan masyarakat yang dalam bahasa Jawa disebut Kawula lan gusti. Dengan Gusti dimaksud sebagai lambang persatuan rakyat yang merdeka yang terdapat dalam kehidupan keluarga dimana tidak ada aturan paksaan, penindasan, perampasan kebebasan, perlawanan seperti lazimnya terlihat dalam alam yang tak ada kemerdekaan. Dalam kehidupan kekeluargaan terdapat aturan berdasarkan cinta kasih (yakni Gusti yang tidak terlihat) menuju tertib dan damai buat masing-masing anggotanya ${ }^{53}$ "Keluarga"

51. Pendapat Pieree Joseph Proudhon dicuplik dari Paul Edwards [ed] The Encyclopedie of Philosophy, Vol V New York MacMillan Publishing, Co inc \& The Free Press, 1972, hal 508.

52. M. Nasroen, Asal Mula Negara, Jakarta, Aksara Baru, 1936, hal. 91. 
sebenarnya berasal dari perkataan "kawula" dan "warga". Kawula berarti "abdi" yang berkewajiban mengabdikan diri dan menyerahkan segala tenaganya kepada yang olehnya dianggap "tuanya". "Warga" berarti "anggota" yang berwenang ikut mengurus, ikut memimpin dan menetapkan segala apa yang diperlukan. Jadi, Kawula Gusti menggambarkan kedudukan yang ganda sebagai "abdi" tetapi sekaligus juga sebagai "tuan". Suatu ciri kehidupan kekeluargaan adalah sikap toleransi. Selain itu masih ada unsurunsur persatuan yang tidak kalah pentingnya yaitu adanya demokrasi dan kesejahteraan bersama. Demokrasi disini bukan hanya berarti "sama-rata" seperti pengertian demokrasi Barat tetapi juga "sama-rasa". Istilah sama rata dan sama rasa mengandung pengertian: demokrasi yang mengandung keadilan sosial. ${ }^{54}$ Suku-suku bangsa Indonesia yang lain juga bersifat komunal seperti masyarakat Jawa, maka pada hakekatnya hal-hal yang diuraikan oleh $\mathrm{Ki}$ Hadjar Dewantara berlaku juga bagi sukusuku bangsa lain. Dengan demikian konsep tersebut tidak sesempit seperti dikatakan oleh Kotan Y. Stefanus.

\section{Pengertian citanegara}

Salah satu paragrap dalam tulisan Kolan Y. Stefanus berjudul "Cita Negara Pancasila: Alternatif Menuju Demokrasi Pancasila". timbul pertanyaan yang dia maksud dengan citanegara, dan apakah dengan demikian tidak terjadi percampuradukkan antara citanegara dan cita huküm.

Dalam Penjelasan UUD 1945 secara jelas diuraikan bahwa pokok-pokok pikiran yang terkandung dalam Pembukaan mewujudkan cita hukum (rechtsidee) yang menguasai hukum dasar negara, baik hukum yang tertulis maupun hukum yang tidak tertulis. Menurut $\mathrm{H}$. Moh. Koesnoe, cita hukum dari suatu budaya berisi nilai hukum yang telah diramu dalam kesatuan dengan nilai-nilai lain-lainnya yang berasal dari kategori nilai-nilai lainnya yang menunjukkan pula sejauh mana phenomena kekuasaan terintegrasi padanya ${ }^{55}$. Dikatakan selanjutnya bahwa cita hukum mempunyai dua segi: segi formal dan segi materiil. Segi formalnya adalah sebagai wadah nilainilai hukum yang telah digarap dengan memperhitungkan alam kenyataan sekeliling kelompok yang bersangkutan. Segi materiil ata's substansialnya adalah nilai hukum.yang telah diramu dalam satu kesatuan dengan nilai-nilai dari kategori nilai lain-lainnya termasuk phenomena kekuasaan, menurut cita rasa budaya masyarakat yang bersangkutan. Menurut Koesnoe, halhal yang menentukan adalah tuntutan alam nyata sekeliling dan rasa cita budaya atau flisafat yang mendasari cita rasa dalam meramu tersebut. Roeslan Saleh mengatakan bahwa cita hukum adalah penentu arah kehidupan sebagai rakyat yang teratur ${ }^{56}$. E.M.H Hirsch Ballin mengatakan bahwa cita hukum harus dilihat dalam konteks historis-kultura[57. Menurut Rudolf Stammer, cita hukum adalah konstruksi pikir yang merupakan keharusan untuk mengarahkan hukum kepada cita-cita yang diinginkan masyarakat. Cita hukum berfungsi sebagai

53. Ki Hadjar Dewantara, "Pendidikan Keluarga", Majalah Keluarga, Tahun ke -1 No 11, Oktober 1937.

${ }^{54 . K i ~ H a d j a r ~ D e w a n t a r a ~ " H i d u p ~ K e l u a r g a ~}$ sebagai sendi persatuan" Majalah Pusara, Juli 1958, Jilid XX No 4.

$55 \mathrm{H}$ Moh Koesnoe, "Perumusan dan Pembinaan Cita Hukum dan Asas-Asa Hukum Nasional" Varia Peradilan No 120 Edisi September 1996, hal 91-137.

56. Roeslan, Asas Hukum Nasionảl, Karya Dunia Fikir, 1996, hal 15.

57. E.M.H. Birsch Ballin Rechsstaat \& Beleid Zwolle, W.E.J. Tjeenk Willink, 1991, hal. 18. 
penentu arah bagi tercapainya cita-cita masyarakat. Cita hukum mempunyai dua sisi: dengan cita hukum dapat diuji hukum positif dan cita hukum mengarahkan hukum positif58. Paul Scholten berpendapat bahwa cita hukum pada tingkat akhir didasarkan kepada moral atau pandangan hidup ${ }^{59}$. Menurut S.W. Couwenberg, cita hukum selain berfungsi sebagai sumber inspirasi bagi perkembangan hukum positif, juga berfungsi sebagai paradigma bagi ilmu hukum yang memetakan dan menginterpretasikan tertib hukum yang berlaku. Dengan begitu ia berperan sebagai pengarah dan pemberi inspirasi kepada proses pembentukan hukum dan penemuan hukum ${ }^{60}$ Oleh karenanya dapat dimengerti pendapat Gustav Radbusch yang mengatakan bahwa tanpa cita hukum maka hukum akan kehilangan maknanya sebagai hukum ${ }^{61}$ dan pendapat Couwenberg yang mengatakan bahwa cita hukum, asas-asas hukum dan hukum tata negara tidak dapat terlepas satu dari yang lain dan harus dilihat dalam hubungan itu. Penulis berpendapat bahwa cita hukum merupakan suatu ukuran yang isinya adalah pandangan etis, filsafati, dan politis dari bangsa yang bersangkutan d.h.i. bangsa Indonesia sebagaimana terkandung dalam Pembukaan UUD 1945 tegasnya Pancasila. Dari situlah kemudian disadur asas-asas hukum yang mengarahkan hukum tertulis dan hukum tidak tertulis di Indonesia.

Cita negara (staatsidee) tidaklah sama dengan cita hukum (rechtsidee). Mengenai pengertian citanegara penulis sependapat dengan Abdul Hamid SA dengan mengikuti pakar hukum Belanda J. Oppenheim yang mengatakan bahwa citanegara adalah hakekat negara yang paling dalam yang dapat memberi bentuk pada negara ${ }^{62}$

Dengan demikian hakekat negara Republik Indonesia yang terkandung dalam citanegara integralistik adalah proses integrasi yang terus-menerus baik secara horizontal maupun secara vertikal. Hal ini adalah sesuai dengan pengertian dinamis yang dianut para Bapak Pendiri Negara RI mengenai pengertian negara yaitu bahwa negara tidak lain ialah seluruh masyarakat atau seluruh rakyat Indonesia sebagai persatuan yang teratur dan tersusun. Dengan demikian citanegara integralistik tidak identik dengan cita hukum berdasarkan Pancasila.

\section{Teori Bernegara bangsa Indonesia}

Citanegara integralislik dan cita hukum yang berdasarkan Pancasila merupakan landasan penyusunan teori bemegara yang dianut oleh UUD 1945. Teori bemegara tersebut menetapkan tujuan negara, fungsifungsi negara, asas-asas kehidupan serta perkembangan negara, dan sistem kekuasaan negara, yang menjadi dasar pengorganisasian dan pengembangan negara.

Tujuan negara sebagaimana dikemukakan oleh Ki Hadjar Dewantara dan ditegaskan dalam Pembukaan UUD 1945 adalah mewujudkan keadilan sosial bagi seluruh rakyat Indonesia. Untuk dapat mencapai tujuan tersebut, fungsi-fungsi negara adalah fungsi integrasi, fungsi pemeliharaan ketertiban dan keamanan umum,fungsi pemeliharaan kesinambungan hidup negara, dan fungsi kesejahteraan masyarakat.

58. Roeslan Saleh Op Cit, hal 16
59. H.J. van Eikema Hommes "De rechsbeggin volgens de transcedental-empirische methode" dalam G.J. Scholten et.al. Rechtsbegiinselen, Zwolle, W.E.J.Tjennk Willink, 1980, hal 36.

60. S.W. Couwenberg, Een nieuwe kijk op staatsrecht en staatsrechtbeofening, Kok Agora, 1992, hal.9.

61. Roeslan Saleh Op. Cit, hal 17.

62. Abdul Hamid S.A. Op.Cit hal 50 
Demokrasi yang dianut oleh UUD 1945 tergambar dari asas-asas yang meliputi kehidupan dan perkembangan negara yang berfungsi sebagai dasar dan sumber materiil bagi pengorganisasian dan prosedur kerja negara. Ada asas-asas yang secara eksplisit diuraikan dalam UUD 1945 letapi ada juga yang secara implisit. Asas-asas yang secara jelas terumuskan dalam UUD 1945 adalah asas kedaulatan rakyat, asas permusyawaratan, dan asas kekeluargaan. Yang secara jelas tergambar adalah asas negara hukum, asas kontrol, asas keterbukaan, asas pembagian kekuasaan, dan asas kepemimpinan. ${ }^{63}$.

Berdasarkan hal-hal tersebut di atas dapat disimpulkan bahwa demokrasi Indonesia berbeda dengan demokrasi Barat yang didasarkan pada falsafah individualisme. Pembangunan negara demokrasi dan pemerintahan yang demokratis tidaklah mudah dan memerlukan waktu yang lama: Hal ini telah diaiami oleh negara-negara lain, dan kini sedang dialami oleh bangsa Indonesia. Pembangunan kehidupan yang demokratis merupakan tanggung-jawab dari semuanya, para penyelenggara negara, para pemimpin masyarakat, para intelektual, para pengusaha, para pemuda, dan para anggota masyarakat lainnya. Tetapi di negara-negara Dunia Ketiga seperti Indonesia peranan para penyelenggara negara dan pemimpin masyarakat merüpakan faktor yang menentukan sekali.

\section{Penutup}

Sekarang ini belum terdapat suatu communis opinio doctorum mengenai teori bernegara bangsa Indonesia. Hal ini sangat disesalkan, sebab bagaimana dapat membangun kehidupan demokrasi di Indonesia kalau mengenai hal-hal yang sangat mendasar sebagaimana diuraikan di atas tadi masih belum memperoleh kesepakatan.

Oleh karena itu tulisan seperti tulisan Kotan Y. Stefanus perlu disambut dengan baik karena merupakan suatu usaha untuk mendalami teori bemegara bangsa Indonesia yang berdasarkan UUD 1945. Tulisantulisan seperti itu walaupun mengandung perbedaan-perbedaan pendapat sangat diperlukan. Dari perbedaan-perbedaan pendapat yang terjadi dan diskusi yang menyusul serta kesimpulan yang dihasilkanya akan lebih mendekatkan kita kepada teori bemegara yang terkandung dalam UUD 1945.

Lebih dari limapuluh tahun yang silam para Bapak Pendiri Negara R.I. telah menghasilkan suatu UUD yang sesuai dengan kebudayaan bangsa Indonesia. Kini tiba giliran generasi yang kemudian untuk mengembangkannya dan melahirkan teori-teori mengenai kehidupan negara dan bangsa berdasarkan UUD 1945.

${ }^{63}$ A.S.S. Tambunan, Fungsi Dewan Perwakilan Rakyat Republik Indonesia Menurut UUD 1945, Suatu Analisis mengenai pengaturanya tahun 1996-1997, Djakarta, Program.Pascasarjana U!, 1998, hal 115. et. 